\title{
Margolis on Realism and Idealism
}

\section{Sami Pihlström}

\section{OpenEdition}

\section{Journals}

Electronic version

URL: http://journals.openedition.org/ejpap/737

DOl: 10.4000/ejpap.737

ISSN: 2036-4091

\section{Publisher}

Associazione Pragma

\section{Electronic reference}

Sami Pihlström, " Margolis on Realism and Idealism », European Journal of Pragmatism and American Philosophy [Online], IV-2 | 2012, Online since 24 December 2012, connection on 30 April 2019. URL : http://journals.openedition.org/ejpap/737 ; DOI : 10.4000/ejpap.737

This text was automatically generated on 30 April 2019.

\section{(c) (i) $\odot$}

Author retains copyright and grants the European Journal of Pragmatism and American Philosophy right of first publication with the work simultaneously licensed under a Creative Commons AttributionNonCommercial-NoDerivatives 4.0 International License. 


\title{
Margolis on Realism and Idealism
}

\author{
Sami Pihlström
}

1 Joseph Margolis has written on the problem of realism voluminously over several decades - in addition to the enormous number of other philosophical debates he has contributed to in original ways. His latest book, Pragmatism Ascendent, ${ }^{1}$ discusses a wide spectrum of philosophical issues, including the transformations of transcendental philosophy today in terms of (Hegelian) historicity and 'flux,' as well as the question of "what it is to be a human self" (Margolis 2012: x), but once again the realism debate is one of the central themes covered, to a large extent in relation to these other complex debates. In this brief paper, I will examine Margolis's arguments for the special kind of integration of realism and idealism (or "Idealism," as he prefers to write) ${ }^{2}$ in relation to his attempt to develop a viable version of pragmatism conscious of its Kantian and especially Hegelian roots, yet promising to develop the pragmatist tradition further in philosophy today.

***

2 Margolis's overall argument is, as usual, complicated, and it would be impossible to even try to summarize it here. One of his characterizations of what the book offers is this: "a descendent $^{3}$ strategy argumentatively (or genealogically) derived from the transcendental turn turned pragmatist by refusing to concede any strong disjunction between broadly 'empirical' first-order inquiries and broadly 'rational' second-order speculations about the legitimacy of both the first and the second" (4). In this context of inquiry, the realism issue is never the primary topic; it is commented on repeatedly as the genealogical and quasi-transcendental examinations of Hegel's response to Kant, of Peirce's fallibilism, and of the inadequacies of contemporary philosophy of mind and social ontology unfold. These philosophical and metaphilosophical contexts turn out to be relevant to the very special - indeed highly unusual - integration of realism and Idealism that Margolis proposes.

3 The first substantial comment on the realism issue in the volume is this, from the opening of Chapter 1: 
The viability of the transcendental question (apart from the fortunes of transcendentalism) makes no sense, unless we also concede that the viability of empirical realism cannot be separated from "idealism" (the "Idealism" already implicated in the transcendental question itself): that consideration already signals the importance of deciding whether the human version of "reason" reflexively affects what we affirm to be possible regarding "what there is" in the whole of reality independent of human cognition. [...] I take "realism" and "Idealism" to be inseparable within any "constructivist" form of realism - it being the case that there is no other viable form of realism. I take that to be both Hegel's and Peirce's view. (8)

4 So realism is maintained: there is something that can be called 'reality independent of human cognition,' and we can and do, quite legitimately, affirm things about 'what there is' in that reality. Yet this is something that we affirm, or fail to affirm, and the transcendental question (that is, the second-order question concern legitimation itself), as Margolis notes, reflexively addresses whether human reason - its structure, or perhaps its history - inevitably affects these affirmations. Thus, realism, when considered transcendentally, cannot be all-inclusive or full-blown. It must be restricted to a human perspective available in a pragmatic analysis.

5 This is what it means to take the issue of realism not just metaphysically but also epistemologically seriously: we need to construe a form of realism that we are able to live with' within our always inevitably historically situated and finite inquiries, processes that are themselves continuously in flux. There is no return to what Kant labeled 'transcendental realism' (which, notoriously, conflates appearances with things in themselves) or to what Hilary Putnam two centuries later famously called 'metaphysical realism' (which postulates a 'God's-Eye View' on the world). These appeals to an imagined super-human perspective on what there really is go considerably beyond the more minimal realism that Margolis favors, a realism that accepts the idea that there is such a reality independently of us but insists on there being only human views or perspectives no divine ones - on that reality. Margolis repeatedly reminds us (e.g., 30) that we construct our "pictures" of reality, but not reality itself, even when the inseparability of realism and Idealism is recognized.

Constructivism, for Margolis, is fully compatible with realism and does not entail any "ontic construction of the whole of 'reality' itself" (39). Accordingly, while what we, within Idealism, may find 'determinately real' presupposes 'the ability of a cognitive agent to discern the fact,' this by no means requires the real world to be constructed by such agents; again, 'what is constructed is one or another picture of the world' (59-60) presumably including, reflexively, this very picture of realism itself. Charles S. Peirce's realism, in particular, is a "constructivist posit supported in terms of what we rationally Hope holds true at the end of infinite inquiry" (60). This is - and here Peirce's special kind of fallibilism truly comes into the picture - because realism cannot be a "free-standing epistemological option," if inquiries "must be infinitely extended"; rather, realism requires (possibly a naturalized version of) an "Idealist supplement" (73).

Given his Peircean elaborations, it is easy to see that Margolis's realism is not just the minimal affirmation that there is something we never constructed. It is a significantly richer position, accommodating an acknowledgment of realism itself being a distinctively human conception of reality. Our realism itself is a 'human face' that the world, as seen from our human perspective, has. ${ }^{4}$ Realism, as Margolis has put it is several previous 
publications, is a human 'posit' rather than the world's 'own' picture of itself. It is not Nature's 'own' image of itself but our image of the world, natural and historic-cultural. ${ }^{5}$

How is this view on realism and Idealism related to pragmatism, and the historical developments that led to the emergence (and the current re-emergence) of pragmatism? Margolis links these processes of development with Peirce's peculiar fallibilism, which along with "the inseparability of realism and Idealism" is one of the defining features of "the sense in which pragmatism [...] cannot fail to be construed as an ingenious and especially promising spare variant of Hegel's own undertaking, now naturalized [...]" (10). Hegel, then, is Margolis's historical hero - not Kant, even though Kant was the first to insist on the compatibility of realism and idealism (or, more specifically, empirical realism and transcendental idealism). Indeed, Kant's account of empirical realism is claimed to be "completely subjectivist" and incoherent by Hegelian lights (10); Kant cannot "recover any robust form of empirical realism" (20). The proper recovery of realism then eventually takes place, after Hegel, in Peirce; indeed, Peirce and Hegel form the pair of philosophical heroes that Margolis celebrates throughout the book.

It is understandable that Margolis emphasizes Hegel's role as a background figure of pragmatism in contrast to Kant's. The latter has been emphasized by other pragmatism scholars (including the present author), and Hegel has often been unduly neglected. Margolis's criticism of Kant's arguments for transcendental idealism could be compared to Kenneth Westphal's, who also suggests that Hegel was the first "pragmatic realist." 6 Westphal could, I believe, easily join Margolis in acknowledging that "objectivity becomes historicized and constructivist" in a pragmatist reinterpretation (or, as Margolis says, "fragmentation") of Hegel's "recovery of realism" (21) and that Hegel's critique of Kant leads to a robust realism about the objects of experience.

Given that this narrative plays a very important role in Margolis's overall argument, it might have been appropriate for him to acknowledge Westphal's work, both his careful historical examinations of both Kant's and Hegel's arguments and his more systematic efforts to show both that Kantian transcendental idealism is not a viable option - neither for Kant himself, given his anti-Cartesian and fallibilist approaches, nor for us - and that the realist can nevertheless argue transcendentally (yet fallibly). The reader familiar with Westphal's ideas would find a comparison highly valuable.

11 While the key figure of Margolis's first chapter is Hegel, the central philosopher of the second one is Peirce. Margolis there argues that Peirce develops further the Hegelian unity of realism and Idealism - to the extent that it would be wrong to say that Peirce was a realist and an Idealist (54). He is both but not in the disjunctive sense these doctrines are traditionally understood in relation to each other. On Margolis's reading, Peirce "believed that it was only within the terms of his Idealism that the realist thesis would prove compelling at all" and therefore "saw no viable disjunction in pressing the realism of science and the need for an Idealist metaphysics" (54). Or, more precisely, Peirce was "not a realist and also, independently, an Idealist" (55); these two doctrines could not coherently be maintained independently according to him (or so Margolis urges). ${ }^{7}$ What 
Peirce uniquely developed, in a post-Hegelian environment, is a constructivist (Idealist) version of scientific realism.

By emphasizing the inseparability of realism and Idealism, or the inevitable embeddedness of realism in constructivism, in Peirce, Margolis insightfully criticizes some of the leading more strongly realist interpreters of Peirce, all the way from Max Fisch to Cheryl Misak and others. ${ }^{8} \mathrm{He}$ also suggests - as he has done on a number of earlier occasions - that Peirce's scholastic realism about the reality of 'generals' should be replaced by a constructivist account of "predicable 'generals"' (76). ${ }^{9}$ Such generals, in a way, are not independent of human thought (78) - though again I would rather emphasize their transcendental dependence and, correspondingly, empirical independence.

Margolis recognizes very important similarities in Peirce's and Dewey's fallibilisms and their versions of the union of realism and Idealism, which, in Dewey, is more explicitly naturalized and evolutionarily laid out. Where Margolis in my view goes wrong is in his neglect of William James. He claims that James was "little more than a secondary figure" in comparison to the two other great classical pragmatists (86) and speaks about the "damage of James's well-known, attractive informality" (90) and even about his "disastrous" conception of truth (92). Even though he may be right to point out that the realization that the Peircean notion of what is "independent of the vagaries of you and me" is itself constructed by pragmatist means does not validate James's account of truth as such (106), he unfortunately seems to ignore James's independent role in the development of the pragmatic method - and in the pragmatist articulation of the realism issue in terms of that method, which in effect makes ontology dependent on, or entangled with, ethics. ${ }^{10}$

\section{米}

Occasionally - to go backwards in the historical story Margolis is telling us - it also seems to this reader at least that Margolis fails to do full justice to Kant's transcendental considerations. For example, though I very much appreciate Margolis's Hegelian and Peircean project of 'pragmatizing' and historicizing Kant, I remain unconvinced by the criticism that Kant does not introduce "a working distinction between appearances and the objects they are appearances of" (19). A 'one world' Kantian response to this charge is obviously that appearances are appearances of things in themselves; these are not two different classes of objects (as more traditional 'two worlds' interpretations maintain) but, rather, the 'same' objects considered from two different perspectives, or articulated through two different considerations. ${ }^{11}$ Moreover, Margolis does not pay due attention to the distinction between the quite different empirical and transcendental ways in which, say, space and time can be said to be 'in us' (29). He partly relies on P. F. Strawson's relatively conventional interpretation which has been heavily criticized by several 'one world' Kantians. Margolis thus claims repeatedly that Kant's transcendental question is incoherent from the very start, but he never (as far as I can see) explains in any great detail, or in full communication with relevant recent scholarship, why this is so. This is a serious setback in his otherwise admirable treatment of the realism issue.

The story of the development of pragmatism can, it seems to me, be told by starting from Kant - and partly skipping Hegel - just as it can be told (and is generally compellingly told by Margolis) by beginning from Hegel's historicization of Kant. Such a story, even when it remains more Kantian than Hegelian, may also join Margolis in rejecting any 
"principled disjunction between the empirical and the transcendental" (30). ${ }^{12}$ In brief, I remain somewhat unconvinced by Margolis about the idea that it is only Hegel, not Kant, who offers a compelling version of the inseparability of realism and Idealism. Kant rejects such an exclusive disjunction as firmly as Hegel.

Margolis is in fact relatively modest when insisting on the possibility of preserving the distinction between metaphysical and epistemological questions even given the "constructivist" character of his realism. He could have gone further by saying that inasmuch as realism itself is inevitably constructivist (pragmatic), all metaphysical questions about the way the world is are inevitably also epistemological, or invoke epistemological positioning. This would yield a more radical pragmatism. In fact such an entanglement of the metaphysical and the epistemological would have been a more Kantian position and would come closer to a Kantian-cum-pragmatist (instead of Hegelian-cum-Peircean) naturalization of transcendental philosophy.

Next, take a look at this:

Kant defeats the realist metaphysics of the rationalists all right; but, then, he also obliges the "objectivity" of science and metaphysics to depend on transcendental (subjective) sources and, in doing that, he makes "empirical realism" no more than an artefact of those same subjective sources: accordingly, he cannot separate, as Hegel can, epistemological and metaphysical constructivism. (39)

But isn't Margolis in his own way doing more or less the same when making realism constructivist? Epistemological and metaphysical versions of constructivism may themselves be claimed to be entangled, necessarily, in a (Kantian) transcendental sense, while of course being disentangled at the empirical level. (We do not construct the world in any empirical, factual, or concrete sense - here I of course agree with Margolis. But it does not follow that the concept of construction fails to do important transcendental work that is not just epistemological but also, albeit in a qualified sense, metaphysical.) Similarly, the claim that Kant's objects are mere "internal accusatives of subjective experience itself" (40) is misleading, because, again, we can endorse a one world reading (à la Allison and others) and view empirical objects and things in themselves as (ontologically) identical and only methodologically distinguishable.

Therefore, when Margolis writes that (once again) Peircean "Idealism" is "construed 'epistemologically' (in the constructivist way) rather than 'metaphysically' (disjunctively)" and is thus restricted to "our constructed picture" of reality rather than the "actual 'constitution' of reality itself" (91), one might ask whether he isn't himself resorting to new versions of dichotomies or disjunctions he wants to set aside. Instead of the realism vs. Idealism dichotomy, we now have (still) the one between metaphysics and epistemology, and also the corresponding one between our picture of reality and reality in itself. Note that these dichotomies - or, to be fair, more absolute versions of them - are standardly used in the kind of mainstream analytic philosophy that Margolis wisely wants to leave behind. In my view, all these dualisms should be critically examined in terms of the pragmatic method and thereby aufgehoben as versions of the age-old subjective vs. objective disjunction to be given up (at least in its conventional versions) in any viable post-Kantian (and post-Hegelian) pragmatism.

Yet, my proposed re-entanglement of the metaphysical and the epistemological at the transcendental level - the level at which constructivism provides a framework for any viable realism - must somehow also accommodate the (re-)entanglement of the transcendental and the empirical. Here I see the real challenge for the current pragmatist 
who wishes to develop further the insights of naturalized transcendental philosophy and apply them to the realism debate. However that challenge can be met, the pragmatist can certainly agree with Margolis's 'précis':

We must, as realists, replace representationalism with some form of constructivism; [...] we must, again as realists, avoid characterizing reality as itself constructed [...] and hold instead that what we construct are only conceptual "pictures" of what we take the real world to be [...]; and [...] we must acknowledge that the realism thus achieved is itself cognitively dependent on, and embedded in, our constructivist interventions. (55)

This can, I think, be offered as a useful characterization of the program of pragmatic realism, insofar as we are able to give up Margolis's in my view too sharp distinction between (the construction of) reality itself and our pictures of it. When developed in Margolis's way, pragmatic (constructivist) realism is reflexively conscious of its own status as a human pragmatic posit rather than an imagined God's-Eye View picture of how things absolutely are. Ironically, Margolis notes, "Peirce's most strenuous insistence on reality's being independent of belief [...] is, contrary to what he actually says, not "independent of what anybody may think them to be"' (85). For the reflexively sophisticated pragmatist, the real is indeed independent of what anyone of us thinks, but this independence is always inevitably affirmed within and on the basis of human thought.

\section{米}

Even if I mildly disagree, in the manner explained above, with Margolis on Kant's place in the story of pragmatism that needs to be told, and in the ways in which the story could continue into the future, I warmly agree with him on the deep integration, or even inseparability, of realism and Idealism - and even Idealism and naturalism, because these need not be any more incompatible than realism and Idealism in Margolis's Hegelian pragmatism. I would again simply prefer to rephrase this in Kantian transcendental terms. I also agree that this transcendental approach itself, though naturalized within pragmatism, precludes any reductive naturalism or eliminativism, which in a sense presuppose the God's-Eye View that only stronger forms of realism (avoiding any link to any form of idealism) try to help themselves to. Margolis's criticism of Wilfrid Sellars is relevant here: the scientific image, he says, "is itself a proposal advanced by the same intelligence that, on his [Sellars's] own argument, congenially offers the 'manifest image"' (26). ${ }^{13}$ Similarly, I agree with Margolis on the need to develop a truly nonreductive philosophical anthropology of the human self (or person), which is something very different from what is done within in mainstream philosophy of mind today - a field of philosophy that has for a long time just ignored pragmatism. Moreover, perhaps one of Margolis's most genuinely innovative ideas is the link he builds between the two postHegelian and post-Darwinian topics he elaborates throughout the book, "the historicity of the human world and the artifactuality of the self" (51).

There would be much more to say - about the artifactual self, its cultural emergence, intentionality (or, again, 'Intentionality,' as Margolis prefers; see, e.g., 143), ${ }^{14}$ the relations between the natural and the human sciences, and many other topics, including the endlessly disputable interpretations of philosophers such as the classical pragmatists, Ernst Cassirer, and John Searle (all of whom Margolis discusses in some detail). Clearly, (re)connecting all this with the realism issue, the main topic of this paper, would lead us 
too far. In any event, Margolis's book, once again, offers plenty of food for philosophical thought on fundamental issues that are with us to stay, whether one's interests lie primarily in realism, philosophy of science, or philosophical anthropology.

Admittedly, what Margolis has provided us with by publishing this new book is yet another relatively general and wide-ranging survey of the field of philosophy and the prospects of pragmatism in the field quite generally, instead of any fully worked-out detailed theory of any specific issue (even realism and Idealism). Even so, his discussion does include a number of highly illuminating new formulations of age-old problems, historical and systematic, as well as new ways of understanding how those problems and some of the proposed answers to them have been, and are, made possible. The historically sensitive pragmatist - and any pragmatist interested in philosophy's future should be historically sensitive - should take Margolis's reflections seriously, both regarding the realism debate and more generally.

\section{BIBLIOGRAPHY}

ALLISON H. E., (2004), Kant's Transcendental Idealism: An Interpretation and Defense - A Revised and Enlarged Edition, New Haven, NH, Yale University Press, 2nd ed. (1st ed., 1983).

MARGOLIS J., (1984), Culture and Cultural Entities, Dordrecht, D. Reidel.

MARGOLIS J., (1986), Pragmatism without Foundations, Oxford, Blackwell.

MARGoLIS J., (1995), Historied Thought, Constructed World, Berkeley, CA, University of California Press.

MARGolis J., (2010), Pragmatism's Advantage, Stanford University Press, Stanford, CA.

MARGolis J., (2012), Pragmatism Ascendent: A Yard of Narrative, A Touch of Prophecy, Stanford, CA, Stanford University Press.

PIHLSTRÖM S., (2003), Naturalizing the Transcendental: A Pragmatic View, Amherst, NY, Prometheus/ Humanity Books.

PIHLSTRÖM S., (2009), Pragmatist Metaphysics: An Essay on the Ethical Grounds of Metaphysics, London, Continuum.

PUTNAM H., (1990), Realism with a Human Face, ed. J. Conant, Cambridge, MA, Harvard University Press.

WESTPHAL K. R., (2004), Kant's Transcendental Proof of Realism, Cambridge, Cambridge University Press.

\section{NOTES}

1. The unspecified page references in the text are to this book (Margolis 2012). 
2. I will continue to write 'Idealism' when referring to the kind of idealism Margolis subscribes to (and finds compatible with realism). This must be distinguished from some more traditional idealisms that are contrasted with realism. The difference between the two doctrines (or sets of doctrines) is that 'idealism' is "either independent of or neutral with regard to 'realism' or disjunctively opposed to 'realism'," while 'Idealism' with a capital 'I' is "hospitable to incorporating some forms of constructive 'realism"' (91).

3. The book title, however, suggests an ascendence of pragmatism (!). Presumably, we are being told that ascendence and descendence are not incompatible and may both be needed as philosophical strategies.

4. Compare this to Hilary Putnam's notion of realism with a human face as developed in Putnam 1990.

5. Margolis's other relevant discussions of realism include, e.g., Margolis 1986 and 1995.

6. See, e.g., Westphal 2004.

7. He also points out that "Peirce's fallibilism is meant to explain just why we cannot, post-Kant and post-Hegel, fall back again to any separate realism or Idealism" - and that John Dewey's version of fallibilism in a way inherits this feature from Peirce's (67), even though the realism/ Idealism issue is only marginally present in Dewey in comparison to Peirce (69-70).

8. He remarks, also, that "most of those who have followed Max Fisch's reading of Peirce are also committed to what Putnam opposes as the "God's-Eye view"' (170, n26.). This relation between the two slightly different realism disputes would deserve more historical scrutiny.

9. For my own earlier reflections on Peircean realism about generality, already inspired by Margolis's constructivist and historicist account of predicable generals, see Pihlström (2003: ch. 3) and (2009: ch. 6).

10. This is what I argue in Pihlström 2009.

11. Allison 2004.

12. This is what I try to do in Pihlström 2003. Margolis briefly comments on my effort in his previous book (Margolis 2010).

13. In relation to his criticism of reductive naturalism - also a theme to which he seems to return again and again - Margolis emphasizes yet another inseparability, that of the natural and the human sciences $(\mathrm{Ch} .3,22)$. Both are human attempts to inquire into the world whose character we constructively posit.

14. According to Margolis's characterization here, "whatever is culturally significant or significative is inherently Intentional" (Ch. 3, 46). For Margolis's previous discussions of this topic, see, e.g., his 1984 and 1995.

\section{AUTHOR}

\section{SAMI PIHLSTRÖM}

Helsinki Collegium for Advanced Studies

sami.pihlstrom[at]helsinki.fi 